\title{
Regulatory Authority Jurisdiction Authority Code
}

National Cancer Institute

\section{Source}

National Cancer Institute. Regulatory Authority Jurisdiction Authority Code. NCI

Thesaurus. Code C94055.

A coded value specifying the type of governance over which an authority has to make laws and enforce them. 